1. One card should be completed for each nest found, even if only one visit is made. The only exception to this is for a single visit to a icolonynesting species. In this case (under visits), use one line for each nest.

2. Record all cowbird eggs or young.

3. Be accurate. Record only actual observations on the face side of the card. Any additional information such as the cause of failure, nest materials used, or food, may be put on the back of the card.

It is hoped that all professional and amateur observers will participate in this scheme by reporting their obsiervations on a nest record card. A good example of the kind of accurate and detailed information that

\section{A BARN SWALLOW NEST RECORD}

By W. E. Jasper, Struan, Sask.

The first Barn Swallow arrived here on May 2, about 10 days earlier than usual. In a few days he was joined by his mate. They soon got busy building in a bin I had left open for them, and it wasn't too long before they had two eggs. Then something happend. On going into the bin next morning I found one swallow dead on the floor. The other just sat around outside for about a week. As the eggs were deserted I took them out of the nest. I think it was the next morning that I noticed the swallow was gone.

In about two days the swallow whitch had left was back again with another mate. A day or two later, on June 12, I looked in the nest again and found one egg. On June 13 there amateur observers can provide is given in the informal Barn Swallow nest record that follows this article. We print Mr. Jasper's record to illustrate the kind of observations which can be usefully recorded on the nest record card. For a supply of cards or additional information write:

Prairie Nest Records Scheme

c/o Mr. F. W. Lahrman

Saskatchewan IMuseum of Natural History

Regina, Saskatchewan

or Mr. E. L. Fox

1053 Gladmer Park

Regina, Saskatchewan

were two eggs, on June 14 three on June 15 four and on June 16 five. The eggs were laid each morning between 5:30 and 7:00 a.m. On July 1 swallows were out of the eggs, and on July 20 the first young left the nest. On July 21 four were out of the nest and the fifth left on July 22.

By August 1 the five young had moved off. But the old pair stayed. This time they took the notion to build a nest in the garage. As we did not want them building in the garage, we kept the doors shut most of the time. However, whenever the doors were open in the day time they went to work again. Even though the bin where they had raised the five was open for them they did not bother about it. As they could not get much done at the nest in the garage, they seemed to decide that it would be too late in the season by the time they got it built and so they left for the south.

\title{
New Plant Records for Saskatchewan, 1957
}

\section{By John Howard Hudson, Regina}

During the summer of 1957 I had my best results collecting plants in the southeastern part of the province, especially in the lower Souris River valley. I found eight species which seem to be new to Saskatchewan; at least they do not appear in Breitung's recent authoritative catalogue of our flora (American Midland Naturalist, Vol. 58, pp. 1-72, July 1957). Three species here reported (Nos. 2003,
2016, and 2021) Breitung specifically excluded from our flora on account of lack of recent verification cf old reports. All eight plants are found in North Dakota or Manitoba; good descriptions of them will be found in Stevens' Handbook of North Dakota Plants, and Fernald's edition of Gray's Manual of Botany. The plants are:

1993. Celastrus scandens L. Clim- 
bing Bittersweet. A mong other shrubs on steep $\mathrm{N}$-facing slope, $\mathrm{S}$. bank of Souris River valley, S.E.1/4 6-2-7 W.2nd, across from the old powerhouse, Estevan, August 3. This is a twining shrub, 1.5 to 2 meters high, with alternate entire leaves, with no remarkable features except the seed pods. Reddish spherical capsules, about $8 \mathrm{~mm}$. across, split when ripe to reveal yellow seeds embedded in a mass of scarlet fleshy tissue. A common North Dakota and southern Manitoba plant.

1996. Buchloe dactyloides (Nutt.) Engelm. Buffalo Grass. On dry gumbo flat in eroded shale in valley parallel to Souris River, S.W.1/4 17-2-8 W. 2nd, 2 miles W. of Estevan, August 4 . This grass looks superficially like our Alkali grass (Distichlis Stricta) being short, stiff, and grey-green; but the tufts propagate by above-ground runners, not underground rhizomes. This grass is dioecious (only one sex per plant); male flowers much like those of Grama Grass (Bouteloua gracilis); pistillate heads in the leaf axils, small, oddly shaped and woody. Little if at all reported from Manitoba and Alberta; rare in Northern North Dakota (Stevens); a common grass of the American High Plains further west and south. I was very surprised and pleased to run across this plant; I would have expected to find it in the southwest corner of the province rather than in the southeast. But I have not seen it in the former corner, nor have I read of anyone else-doing so.

1998. Asclepias verticillata L. Whorled Milkweed. On dry shaly gumbo prairie, south side valley bottom of Souris River, S.E.1/417-2-8W.2nd, about 2 miles $W$. of Estevan, August 4. This small milkweed may be recognized by the narrow leaves (about $2 \mathrm{~mm}$. wide) arranged in whorls on the stem (20-30 cm. high) and the typical milkweed flowers. These latter are whitish-yellow and much smaller than those of the familiar Showy Milkweed ( $A$. speciosa), being about $4 \mathrm{~mm}$. long. Common in North Dakota.

1999. Carex gravida Bailey. In pen ash-elm woods, W. side valley of Short Creek in N.W.1/4 11-1-7 W.and (about 4 miles S.W. of Roche Percée), Aug. 4. Much like our C. hookeriana, but not densely tufted, a short woody rhizome being present. Quite common in North Dakota.

2003. Aster umbellatus Mill. var. pubens Gray. Flat-top Aster. Moist aspen woodlands near edge of marsh, S. edge N.E. 1/4 3-19-30 W.1st, 6 miles E. of Spy Hill, August 17. A big aster, about a meter high, with lanceelliptic pointed willow-like leaves, and many large $(2-3 \mathrm{~cm}$.) white-rayed heads arranged in a flat-topped cluster up to $20 \mathrm{~cm}$. across. Local in wooded marshes, eastern North Dakota; commoner in Manitoba and eastern Canada.

2016. Helianthus tuberosus L. var. subcanescens Gray. Jerusalem Artichoke. Shady woods (ash, elm, maple) along N. bank Souris River in N.E. $1 / 436-1-3 W .2 n d, 6$ miles north of Northgate, September 14. This big perennial yellow-centered sunflower is distinguished from our usual plants of this type ( $H$. giganteus $\mathrm{L}$. and varieties) by its broad-ovate leaves and the semi-edible tubers on the rhizomes. Common in North Dakota, especially eastward, and throughout the American Mid-West.

2017. Eragrostis hypnoides (Lam.) B. S. P. Creeping Lovegrass. Wet mud on bank of Souris River, S.E. $1 / 4$ 16-1-34W.1st, 2 miles $\mathrm{E}$. and 12 miles S. of Glen Ewen ( 2 miles from U.S. boundary), September 15. This small annual gras possesses prostrate branching culms rooting at the nodes, thus forming mats on mud. The spikelets look much like those of Puccinellia nuttalliana (Salt Meadow Grass) but the panicle is only a few $\mathrm{cm}$. long. Occasional in eastern North Dakota and the central U.S.

2021. Scirpus atrovirens Willd. var. pallidus Britt. Dark-green Bulrush. Poplar bluff in ravine on $W$. side valley of Souris River, S.W.1/4 16-1-34 W.1st, 2 miles from U.S. boundary, September 15. This looks like several other species of cespitose bulrush with inflorescence of many small spikelets subtended by more than on leaf-lke bract, especially $S$. microcarpus Presl.; only technical characters will distinguish it. Common in North Dakota and the central U.S.

Duplicates of these specimens will be sent to the herbarium of the Department of Agriculture at Ottawa, and to the herbarium of the Dominion Laboratory of Plant Pathology at Saskatoon. 